\title{
Pengalaman Guru Bimbingan dan Konseling dalam Menangani Anak Berkebutuhan Khusus
}

\author{
Yahya AD, Siti Kristika
}

Dosen dan Mahaiswa Fakultas Tarbiyah dan Keguruan, IAIN Raden Intan Lampung

Diterima: Oktober 2015. Disetujui: November 2015. Dipublikasikan: Desember 2015

\begin{abstract}
Abstrak: Anak berkebutuhan khusus adalah anak yang mempunyai kelainan tubuh dan mental. Dalam Pendidikan luar biasa atau Pendidikan khusus anak berkelainan, ditujukan kepada anak-anak yang dianggap memiliki kelainan penyimpangan dari kondisi rata-rata anak normal umumnya, dalam hal fisik, mental, maupun karakteristik prilaku sosialnya, atau anak yang berbeda dari rata-rata umumnya, dikarenakan ada permasalahan dalam kemampuan berfikir, penglihatan, pendengaran, sosialisasi, dan bergerak. Penelitian ini bertujuan untuk mendapatkan gambaran tentang pengalaman Guru Bimbingan dan Konseling dalam menangani anak berkebutuhan khusus. Penelitian ini menggunakan desain fenomenologi dengan metode wawancara mendalam. Data yang dikumpulkan merupakan hasil wawancara dan catatan lapangan yang dianalisis, penelitian ini menghasilkan 24 tema. Hasil penelitian menggambarkan perasaan menerima, perasaan marah, perasaan depresi, dan beban waktu. Penanganan yang dilakukan oleh Guru Bimbingan dan Konseling memperlihatkan tujuan dan jenis kebutuhan dengan menggunakan berbagai metode tertentu. Guru Bimbingan dan Konseling membutuhkan dukungan sosial dan sarana prasarana dan telah menggunakan beberapa sumber dan bentuk dukungan selama menangani Anak Berkebutuhan Khusus. Respon lingkungan mengharuskan Guru BK melakukan modifikasi cara mengenai Anak Berkebutuhan Khusus baik dalam sistem pengajaran dan pembelajaran mencakup berbagai hambatan, kurikulum dan materi ajar, kerjasama pemecahan masalah, penilaian siswa, fleksibilitas, akuntabilitas.
\end{abstract}

Kata Kunci: Anak berkebutuhan Khusus, Bimbingan Konseling, Metode Guru

\section{Pendahuluan}

Anak berkebutuhan khusus merupakan masalah yang rumit dan jumlahnya terus menigkat. Jumlah anak berkebutuhan khusus (ABK) di Indonesia pada tahun 2014, diperkirakan mencapai 4,2 juta jiwa. Menurut Badan Koordinasi dan Keluarga Berencana Nasional (BKKBN), menyatakan bahwa jumlah anak usia sekolah sebesar 42.870.041 jiwa, dan 10 persen anak usia sekolah (5-14 tahun) menyandang kebutuhan khusus (Suwarno, 2013). Anak berkebutuhan khusus adalah anak yang mempunyai kelainan tubuh dan mental. Dalam pendidikan luar biasa atau pendidikan khusus anak berkelainan, ditunjukan kepada anak-anak yang di anggap memiliki kelaian penyimpangan, dari kondisi rata-rata anak normal umumnya, dalam hal fisik, mental, maupun karakteristik perilaku sosialnya, atau anak yang berbeda dari rata- rata umumnya, dikarenakan ada permasalahan dalam kemampuan berfikir, penglihatan, pendengaran, sosialisasi, dan bergerak (Prawitasari, 2011).

Berdasarkan pengertian tersebut, anak yang dikategorikan memiliki kelainan dalam aspek fisik meliputi kelainan indra penglihatan (tunanetra), kelainan indra pendengaran (tunarungu), kelainan kemampuan bicara (tunawicara), dan kelainan fungsi anggota tubuh (tunadaksa). Anak yang memiliki kemampuan mental lebih (supernormal) yang dikenal sebagai anak berbakat, dan anak memiliki kemampuan mental yang sangat rendah (subnormal) yang dikenal sebagai tuna grahita, anak yang memiliki kelainan dalam aspek sosial adalah anak memiliki dalam menyesuaikan perilakunya terhadap lingkungan sekitarnya. Anak yang termasuk dalam kelompok ini dikenal sebagai tuna laras (Smith, 2013).

Undang-undang Republik Indonesia Nomor 20 tahun 2003 tentang sistem pendidikan nasional memberikan warna lain dalam penyediaan pendidikan bagi anak berkelainan. Pada penjelasan pasal 15 tentang pendidikan khusus disebutkan bahwa pendidikan khusus merupakan pendidikan untuk peserta didik yang berkelainan atau peserta didik yang memiliki 
kecerdasan luar biasa yang diselenggarakan secara inklusif atau berupa satuan pendidikan khusus pada tingkat pendidikan dasar dan menengah. dan dijelaskan pada pasal 32 ayat 1 tentang pendidikan khusus merupakan pedidikan bagi peserta didik yang memiliki tingkat kesulitan dalam mengikuti proses pembelajaran karena kelainan fisik, emosional, mental, sosial, dana tau memiliki potensi kecerdasan dan bakat istimewa (RI, 2003).

Peraturan menteri Pendidikan Nasional Republik Indonesia Nomor 70 tahun 2009 tentang pendidikan inklusif bagi peserta didik yang memiliki kelainan dan peraturan ini, yang dimaksud dengan pendidikan inklusif adalah system penyelenggaraan pendidikan yang memberikan kesempatan kepada semua peserta didik yang memiliki kelainan dan memiliki potensi kecerdasan atau bakat istimewa untuk mengikuti pendidikan atau pembelajaran dalam satu lingkungan pendidikan secara bersama-sama dengan peserta didik secara umumnya (Permendiknas, 2015).

Oleh karena itu ABK perlu diberi kesempatan dan peluang yang sama dengan anak normal untuk mendapatkan pelayanan pendidikan di sekolah. Sekolah Menengah Pertama Negeri 14 Bandar Lampung. Pendidikan inklusif diharapkan dapat memecahkan salah satu persoalan dalam penanganan pendidikan bagi anak ABK selama ini. Pendidikan inklusif adalah sistem layanan pendidikan yang mensyaratkan ABK belajar di sekolah-sekolah terdekat, di kelas bisa bersama teman-teman seusianya (Abay, 2014).

Dengan adanya masalah yang ada di sekolah maka sangat diperlukannya keberadaan bimbingan dan konseling di sekolah yang berperan untuk membantu peserta didik yang mengalami kesulitan dalam berbagai hal teurtama dalam menangani anak inklusif, disinilah peran guru bimbingan dan konseling di sekolah mulai diperlukan dan bukan saja hanya mengatasi berbagai macam kesulitan peserta didik, akan tetapi juga membantu guru dalam mengenal peserta didiknya secara lebih mendalam sehingga bimbingan dan konseling lebih sisrtematis dan bermutu.

Guru merupakan sebagai pelaku utama dalam implementasi atau penerapan program pendidik disekolah, memiliki peranan yang sangat strategis dalam mencapai tujuan yang diharapkan (Yusuf \& Nani, 2011). Guru mempunyai tanggung jawab untuk melihat segala sesuatu yang terjadi dalam kelas, untuk membantu proses perkembangan anak, guru senantiasa berusaha untuk menimbulkan, memelihara, dan mengingatkan motivasi anak untuk belajar (Ahmadi, 2008).

Bimbingan membantu setiap individu untuk lebih mengenali berbagai informasi tentang dirinya sendiri. Dari berbagai pendapat para ahli dapat disimpulkan bahwa, bimbingan adalah proses pemberian bantuan yang dilakukan dari orang yang ahli kepada seseorang atau beberapa orang individu, baik anak-anak, remaja, maupun dewasa, agar orang yang dibimbingnya dapat mengembangkan kemampuan dirinya sendiri dan mendiri, dengan memanfaatkan kekuatan individu dan sarana yang ada dan dapat dikembangkan berdasarkan norma-norma yang berlaku (Prayitno \& Emti, 2004).

Berdasarakan hasil wawancara peneliti dengan guru SMP Negeri 14 Bandar Lampung bapak Wahyudin, S.Pd., selaku guru Bimbingan dan Konseling yaitu: "bahwa untuk menangani ABK selama anak berada di lingkungan sekolah, hal yang harus ditekankan kepada seluruh warga SMP Negeri 14 Bandar Lampung untuk selalu menyayangi, menghargai, beradaptasi dengan baik, dan selalu berprilaku sabar dan penuh keikhlasan. Sehingga apa yang diharapkan oleh pihak sekolah, orang tua dan berjalan dengan baik, respon dari teman- teman sebaya sangat antusias dengan kehadiaran mereka bisa belajar bersama-sama dengan anak yang normal lainya".

Namun tidak semua berjalan seperti yang kita harapkan, setelah survey pra penelitian, peneliti menemukan guru merasakan kesulitan saat anak mengalami tantrum, sulitnya beradaptasi ABK saat beribadah sehingg mngekibatkan kurang khusuknya shola. Berdasarkan pernyataan tersebut, maka peneliti akan mengungkap lebih lanjut pengalaman Guru Bimbingan 
dan konseling dalam menangani Anak Berkebuthan Khusus dengan menggunakan metode kualitatif dengan pendekatan fenomenologi, karna dengan menggunakan akan dapat menggambarkan pengalaman guru bimbingan dan konseling dalam menangani anak ABK.

\section{Metode Penelitian}

Penelitian ini adalah penelitian yang bersifat kualitatif, penelitian kualitatif adalah berakar pada latar belakang ilmiah sebagai kebutuhan, mengandalkan manusia sebagai alat penelitian, memanfaatkan metode kualitatif analistis secara induktif, mengarahkan sasaran penelitian pada usaha menemukan teori, lebih mementingkan proses dari pada hasil, memilih seperangkat kriteria untuk menulis keabsahan data, rancangan penelitian bersifat sementara dan hasil penelitian disepakati oleh subjek penelitian (Maleong, 2001).

Menurut S. Margono penelitian kualitatif adalah prosedur penelitian yang menghasilkan data deskriptif berupa kata- kata tertulis atau uraian dari orang dan perilaku yang dapat diamati (S. Margono, 1997). Metode penelitian kualitatif digunakan untuk meneliti pada kondisi yang alamiah dimana penliti adalah sebagai instrument kunci (Sugiyono, 2008).

Menurut Sanapiah Faisal ada empat alternatif untuk menetapkan permasalahan yang akan diteliti yaitu sebagai berikut: 1) Menetapkan fokus permasalahan yang disarankan oleh informan. 2) Menetapkan fokus permasalahan berdasarkan domain- domain tertentu. 3) Menetapkan fokus masalah yang memiliki nilai temuan untuk pengembangan IPTEK. 4) Menetapkan fokus masalah berdasarkan permasalahan yang tekait dengan teori-teori yang telah ada. Menurut Surnadi Suryabrata, penelitian kualitatf bertujuan untuk: 1) Mencari informasi factual yang mendetail dengan melihat gejala yang ada. 2) Mengidentifikasi masalah-masalah atau untuk mendapatkan justifikasi keadaan dan peraktik-praktik yang sedang berlangsung. 3) Membuat komparasi dan evaluasi. 4) Mengetahui apa yang di kerjakan oleh orang-orang lain dalam menangani masalah atau situasi yang sama, agar dapat belajar dari mereka untuk kepentingan pembuatan rencana dan pengambilan keputusan dimasa depan (Suryabrata, 1997).

\section{Hasil Dan Pembahasan}

1. Perasaan Guru Bimbingan dan Konseling Selama Menangani Anak Berkebutuhan Khusus

Tema 1: Perasaan penuh warna yang disarankan oleh guru bimbingan dan konseling selama menangani anak berkebutuhan khusus adalah perasaan menerima anak, perasaan bahagia, perasaan marah, perasaan depresi, dan beban waktu.

2. Penanganan Anak Berkebutuhan Khusus Yang Telah Di Lakukan Oleh Guru Bimbingan dan Konseling

Tema 2: Tujuan penanganan ABK yang dilakukan oleh guru bimbingan dan konseling adalah agar anak berkebutuhan khusus bias bersama-sama dengan anak normal lainnya, bersosialisasi, beradaptasi dengan baik.

Tema 3: Jenis dan metode yang digunakan dalam menangani ABK, pertama mengklarifikasi dengan semua wali kelas untuk menyapa, menanyakan kondisi ABK, guru bimbingan dan konseling terjun secara langsung melihat keadaan. dan metode yang digunakan guru bimbingan dan konseling memberikan layanan kepada anak, komunikasi, kepatuhan terhadap aturan, melibatkan orangtua, dan mengamati perkembangan anak. 
3. Layanan Guru Bimbingan dan Konseling dalam Menangani Anak Berkebutuhan Khusus

Tema 4: Dukungan Sosial sebagai kebutuhan guru bimbingan dan konseling SMP N 14 Bandar Lampung, sumber dukungan dari Pemerintah, Kepala Sekolah, Wakil KepSek, seluruh dewan guru, dan orangtua anak/wali murid.

Tema 5: Sarana Prasarana merupakan kebutuhan sebagai alat dan penunjang dalam menangani Anak Berkebutuhan Khusus.

4. Sumber Pendukung Guru Bimbingan dan Konseling dalam Menangani Anak Berkebutuhan Khusus

Tema 6: Asal Dukungan dari internal dan eksternal selama menangani Anak Berkebutuhan Khusus.

Tema 7: Bentuk Dukungan merupakan wujud dukungan yang telah diberikan mereka kepada kami guru bimbingan dan konseling, kami diberikan dukungan secara emosional, pendidikan dan serta tunjangan.

5. Hambatan Selama Mengenai Anak Berkebutuhan Khusus

Tema 8: Tuntutan mengenai ABK merupakan berbagai macam keharusan yang semestinya terpenuhi, membimbing anak menjadi lebih baik, memahami anak, mengkontrol perubahan-perubahan sikap dll.

Tema 9: Respon Masyarakat menjadi hambatan sendiri bagi kami, karena menimbulkan stigma di masyarakat untuk menghindari belajar bersama Anak Berkebutuhan Khusus.

6. Cara Penyelesaian Masalah yang di Gunakan Selama Menangani Anak Berkebutuhan Khusus.

Tema 10: Modifikasi Cara merupakan suatu cara untuk mengatasi berbagai keterbatasan yang di alami oleh guru BK dalam hal menurunkan emosi anak pada saat tantrum, dalam hal layanan yang diberikan untuk anak, dan bimbingan.

Tema 11: pengajaran dan pembelajaran mencakup berabagai hambatan, guru melaporkan mengenai penanganan Anak Berkebutuhan Khusus dengan pengahargaan dan keterbukaan sambal memperhatikan cara siswa berinteraksi.

Tema 12: Kurikulum dan Materi Ajar, guru di kelas iklusif melaporkan kepada kami bahwa mereka cenderung tidak melakukan penekanan pada tugas-tugas yang berat tetapi, beralih pada metode yang lebih manipulative dan kreatif.

Tema 13: Sukses untuk Semua, guru harus melaporkan bahwa Anak Berkebutuhan Khusus di kelas dapat memperkuat dan memperdalam komitmen mereka untuk membantu setiap anak untuk berhasil.

Tema 14: Kerjasama Pemecahan Masalah Guru di kelas inklusif melaporkan, lebih bisa melakukan kerja sama antara siswa dengan siswa dan dengan yang terkait.

Tema 15: Penilaian Siswa, guru harus malaporkan kepada kami bahwa anak aktif berperan, dengan tujuan menigkatkan rasa memiliki yang lebih besar bagi siswa berkebutuhan khusus.

Tema 16: Fleksibilitas, guru harus melaporkan bahwa di kelas inklusif mereka lebih fleksibel, memberi mereka perasaan dalam gaya mengajar, struktur, serta dalam menciptakan aktivitas yang akan meningkatkan keberhasilan. 
Tema 17: Biarkan Berjalan, mereka akan lebih memikirkan para siswa berkebutuhan khusus dengan cermat, sesuai dengan bakat, dan minat yang mereka miliki.

Tema 18: Akuntabilitas, tumbuhnya suatu komitmen terhadap berkembangnya etika dan tanggung jawab di dalam penanganan Anak Berkebutuhan Khusus.

Tema 19: Mekanisme Koping merupakan cara yang digunakan Guru BK dalam manghadapi masalah yang di jumpai dalam merawat ABK, yaitu pendekatan spiritual, marah dan mencoba dengan hal-hal yang baru.

Tema 20: Pemberdayaan Orang Tua Pemberdayaan orang tua adalah usaha yang dilakukan untuk menjalin komunikasi yang baik terkait ABK.

7. Harapan Guru BK Selama Menangani Anak Berkebutuhan Khusus

Tema 21: Adanya Perhatian yang kita berikan terhadap Anak Berkebutuhan Khusus, sangat berpengaruh baik dengan dirinya maupun dengan guru- gurunya.

Tema 22: Perkembangan anak sangat dibutuhkan untuk informasi yang lebih baik di dalam menangani ABK, seperti kemampuan berkomunikasi, beradaptasi dengan baik.

8. Makna yang dirasakan oleh Guru BK Selama Menangani Anak Berkebutuhan Khusus

Tema 23: Makna Positif yang dirasakan oleh Guru BK adalah perubahan sikap menjadi lebih sabar lagi, perhatian, special, meningkatkan Ibadan tumbuh motivasi dan selalu menyayangi.

Tema 24: Makna Negatif tekadang merasa ketidakpuasan dalam memberikan layanan terhadap anak.

Sesuai dengan analisis data dan pembahasan dapat di simpulkan bahwa hasil penelitian menggambarkan perasaan menerima, perasaan marah, perasaan depresi, dan beban waktu. Penanganan yang dilakukan oleh guru Bimbingan dan Konseling memperhatikan tujuan dan jenis kebutuhan dengan menggunakan berbagai metode tertentu. Guru Bimbingan dan Konseling membutuhkan dukungan sosial dan finansial dan telah menggunakan beberapa sumber dan bentuk dukungan selama menangani Anak Berkebutuhan Khusus.

Respon lingkungan mengaharuskan guru Bimbingan dan Konseling melakukan modifikasi cara menangani Anak Berkebutuhan Khusus baik dalam system pengajaran dan pembelajaran mencakup berbagai hambatan, kurikulum dan materi ajar. Kerjasama pemecahan masalah, penilaian siswa, fleksibilitas, akuntabilitas. Guru Bimbingan dan konseling mengharapkan adanya perhatian khusus kepada pihak-pihak yang terkait. Guru Bimbingan dan Konseling merasakan perasaan positif dan perasaan negative selama menangani Anak Berkebutuhan Khusus.

\section{Simpulan dan Saran}

Berdasarkan hasil penelitian ini menggambarkan bahwa pengalaman Guru Bimbingan dan Konseling dalam menangani Anak Berkebutuhan Khusus, merupakan pengalaman yang luar biasa berat dan tidak mudah untuk dilalui dalam menghadapi perasaan yang berbagai warna di sepanjang kehidupan dan berbagai hambatan yang di temui.

Kemampuan koping dan pemberdayaan Guru Bimbingan dan Konsling secara efektif serta dukungan sosial yang kuat dari orang tua anak, warga sekolah, lingkungan masyarakat, yang memberikan kekuatan bagi Guru Bimbingan dan Konseling untuk mendapatkan makna yang mendalamdan melukis harapan baru saat menangani Anak Berkebutuhan Khusus. 
Temuan penelitian ini diharapkan dapat di manfaatkan oleh Guru Bimbingan dan Konseling, untuk melengkapi kemampuannya dalam meminimalkan berbagai dampak yang dirasakan oleh Guru Bimbingan dan Konseling saat menangani Anak Berkebutuhan Khusus, melalui pengembangan desain anak dalam konteks penanganan di sekolah inklusif.

\section{Daftar Pustaka}

Abay, K. (2014, desember 11). Retrieved from http://kavrella.wordpress.com/2010/06/16/inklusi-solusi-atau-masalah/

Ahmadi, A. (2008). Psikologi Belajar. Jakarta: Rineka Cipta.

Maleong. (2001). Metode Penelitian Kualitatif. Bandung: Remaja Rosdakarya.

Permendiknas. (2015, februari 2). Retrieved from http://peduliinklusi.blogspot.permendiknasno-70-tahun-2009

Prawitasari, J. (2011). Psikologi Klinis. Jakarta: Erlangga.

Prayitno, \& Emti, E. (2004). Dasar-Dasar Bimbingan Dan Konseling. Jakarta: Rineka Cipta.

RI, D. (2003). Undang-Undang Republik Indonesia Nomor 20 Tahun 2003 Tentang Pendidikan Nasional. Jakarta: Biro Hukum Dan Organisasi Sekretariat Jendral Departemen Pendidikan Nasional.

S. Margono. (1997). Metode Penelitian Kualitatif. Jakarta: Rineka Cipta.

Smith, D. (2013). Sekolah Inklusi. Bandung: Nuansa Candekia.

Sugiyono. (2008). Metode Penelitian Pendidikan: Metode penelitian kualitatif dan R \& D. Bandung: Alfabeta.

Suryabrata, S. (1997). Metodologi Penelitian. Jakarta: Rajawali Pers.

Suwarno. (2013, Desember 31). Jumlah anak berkebutuhan khusus di indonesia. Retrieved from Republika berita: http://.Republika. berita/nasional/umumjumlah-anakberkebutuhan khusus-di-indonesia-tinggi.

Yusuf, S., \& Nani. (2011). Perkembangan peserta didik. Jakarta: Raja Grafindo Persada. 